embryology. He was one of the original members of the Aberdeen University Anthropological Society, to which British archæology is indebted for its contributions by excevation to early studies of the osteology of the 'beaker-folk'. For many years Prof. Low has been an active member of the anthropological section of the British Association.

\section{Oxford's Programme of Development}

A YEAR ago the University of Oxford appealed to its friends for endowment on a scale appropriate to the part it is called upon to play in the world of learning to-day. The response was $£ 426,000$. This sum, with the new foundation of Nuffield College for the study of the social sciences, will provide for many of the needs which were mentioned in the appeal. It is strongly felt, however, that further development should take place, and for this a new appeal, which will remain open until July 31 , has recently been made. The sum now asked for is $£ 250,000$. The most urgent need at the moment is the creation of a general research fund, both for the humanities and for the natural sciences. In the past ten years the number of research students at Oxford has doubled, and throughout the University there is a keen spirit of research. To endow a promising piece of research, whatever it may be, whenever an original line has been struck out, a research fund of $\$ 100,000$ is regarded as essential. For the development of research in archæology it will be necessary to complete the extension of the Ashmolean Museum, and for this $£ 15,000$ will be required. It is felt also that as soon as possible the Departments of Physiology and Botany should have new laboratories. Towards the costs of these $\mathfrak{£ 6 0 , 0 0 0}$ and $£ 40,000$ are required. Lastly, another $£ 35,000$ is needed to complete and maintain the new physical chemistry laboratory that is to be erected. These sums make up the $£ 250,000$ which is being asked for.

\section{Transatlantic Steam Navigation}

IN connexion with the centenary of the inauguration of regular steam passages between Great Britain and the United States by the four steamers Sirius, Great Western, Royal William and Liverpool, which all crossed and recrossed the Atlantic in 1838, a special exhibition has been arranged at the Science Museum to illustrate "One Hundred Years of Transatlantic Steam Navigation". The central feature of the exhibition is the magnificent model of the Queen Mary, the model being $22 \mathrm{ft}$. long. The gallery also contains models of the Normandie, the Conte di Savoia and other notable vessels of recent years. Of greater historic interest, however, are the newly made models of the Sirius and Great Western. The former ship was of only 703 tons gross and was never intended for work in the Atlantic, but she was the - first steamer ever to cross the ocean from east to west using her engines as the main motive power. Her voyage began on April 4, when she left Cork, and ended on April 23, when she tied up in New York harbour. The Great Western, designed by the famous engineer Isambard Kingdom Brunel, was of
1,340 tons and it was she which demonstrated in unmistakable manner the possibilities of steam on the ocean. The original drawings of the ship are shown beside the model, and also various interesting documents. Other ships shown are the Great Britain and the Great Eastern, the Britannia, first of Cunard vessels, the Scotia, the last of the paddle vessels on the Atlantic, the Servia, the first steel liner, and the Philadelphia, the first large twin-screw ship on the Atlantic. The exhibition was opened on March 16, and will remain open until the middle of September. An illustrated handbook has been prepared by $\mathrm{Mr}$. H. P. Spratt, the Museum officer who has arranged the exhibition.

\section{Hadrian's Wall}

Soms major problems of the Roman Wall of Hadrian would appear to have been brought to a solution by recent excavations of the Durham University Excavation Committee, of which an account was given on March 11 before the Society for the Pro. motion of Roman Studies by Mr. I. A. Richmond of King's College, Newcastle-on-Tyne, co-director of the investigation with Mr. F. G. Simpson, of the Cumberland Excavation Committee. It is found that the lack of uniformity between the remains in different sectors of the Wall, which has been the main difficulty of the archæologist, is not due to haphazard work, but arises from deliberate changes in plan as the Wall was in course of erection, as well as to the differences in material available for building. From Newcastle to the Irthing the builders began with a wall of stone $10 \mathrm{ft}$. thick (afterwards reduced to $7 \frac{1}{2} \mathrm{ft}$. to expedite the work), erecting barracks for patrols in large courtyard gateways piercing the Wall at every mile, and hence called 'milecastles'. Over the north gate of each and at every 540 yards was a turret. This section of the Wall was then extended eastward to Wallsend; and a narrow stone wall built to the westward between milecastles 49 and 53 ; but in the main westward extension from the Irthing to Bowness-on-Solway, limestone for grout was lacking, and a turf wall took the place of the stone wall. It was supplied with stone turrets of distinctive type and milecastles of wood. This turf wall was replaced by a stone wall later in the century.

TACTICAL considerations now took the place of time and material, which had previously determined changes in plan. When the Wall was completed, eight forts were embodied in the line, holding either 500 cavalry or a nominal 1,000 infantry. Thus was formed a front line force capable of taking the offensive in overwhelming strength. It had been found that the Wall, designed originally as a patrol line, could be better used for concentrated garrisons, and thenceforward the emphasis was on forts rather than milecastles. Next in order comes the Vallum, the earthwork of which the ditch is the main feature, south of the Wall, the purpose of which has been the subject of much controversy. Mr. Richmond is of the opinion that it demarcates the military zone of the Wall and its 